\title{
Algoritmização de estereótipos raciais em bancos de imagens: a persistência dos padrões coloniais Jezebel, Mammy e Sapphire para mulheres negras
}

Fernanda Carrera ${ }^{1}$

Recebido: 06/10/2020

Aprovado por pares: 16/07/2021
Submetido a pares: $13 / 01 / 2021$

Aceito: 26/07/2021

DOI: 10.5294/pacla.2021.24.3.3

Para citar este artículo / to reference this article / para citar este artigo Carrera, F. (2021). Algoritmização de estereótipos raciais em bancos de imagens: a persistência dos padrões coloniais Jezebel, Mammy e Sapphire para mulheres negras. Palabra Clave, 24(3), e2433. D0I: https://doi.org/10.5294/pacla.2021.24.3.3

\section{Resumo}

Neste trabalho, é realizado um estudo exploratório de bancos de imagens, especificamente Getty Images e Shutterstock, analisando se os processos de tagueamento desses dispositivos de busca revelam modos algorítmicos de reprodução de mentalidades coloniais a respeito de mulheres negras. Com base no conceito de "imagens de controle", de Patricia Hill Collins, foram analisadas aqui as imagens Jezebel, Mammy e Sapphire, a partir do entendimento de que esses estereótipos sobre a subjetividade feminina negra reforçam narrativas de subordinação, exploração e animalização, a serviço da colonialidade. Embora os resultados apresentem especificidades, sobretudo em virtude da pandemia da covid-19, percebeu-se que a colonialidade algorítmica se manifesta nesses bancos, que etiquetam com mais frequên-

$1 \bowtie$ http://orcid.org/0000-0001-5024-0860. Escola de Comunicação, Universidade Federal do Rio de Janeiro, Brasil.fernanda.carrera@eco.ufrj.br 
cia as imagens de mulheres negras a padrões coloniais de representação de sexualidade, trabalho e agressividade.

\section{Palavras-chave (Fonte: tesauro da Unesco)}

Colonialidade; algoritmos; mulheres negras; mulheres afrodescendentes; raça; bancos de imagem. 


\section{Algoritmización de estereotipos raciales en bancos de imágenes: la persistencia de los estándares coloniales Jezebel, Mammy y Sapphire para mujeres negras}

\section{Resumen}

En el artículo, se realiza un estudio exploratorio de bancos de imágenes, específicamente Getty Images y Shutterstock, analizando si los procesos de tagueamento de estos dispositivos de búsqueda revelan modos algorítmicos de reproducción de mentalidades coloniales respeto a las mujeres negras. Desde el concepto de "imágenes de control", de Patricia Hill Collins, se analizaron aquí las imágenes Jezebel, Mammy y Sapphire, a partir del entendimiento de que estos estereotipos acerca de la subjetividad femenina negra recalcan narrativas de subordinación, explotación y animalización, a servicio de la colonialidad. Si bien los resultados presenten especificidades, sobre todo debido a la pandemia de la Covid-19, se encontró que la colonialidad algorítmica se manifiesta en estos bancos, que etiquetan con más frecuencia las imágenes de mujeres negras a estándares coloniales de representación de sexualidad, trabajo y agresividad.

\section{Palabras clave (Fuente: tesauro de la Unesco)}

Colonialidad; algoritmos; mujeres negras; mujeres afrodescendientes; raza; bancos de imagen. 


\section{Racial Stereotype Algorithmization in Image Banks: The Persistence of Jezebel, Mammy, and Sapphire Colonial Standards for Black Women}

\section{Abstract}

This paper presents an exploratory study of image banks, specifically Getty Images and Shutterstock, analyzing whether their tagging processes reveal algorithmic forms of reproducing colonial mentalities about black women. From Patricia Hill Collins' concept of "controlling images," Jezebel, Mammy, and Sapphire images were examined, understanding that these stereotypes of black female subjectivity underscore narratives of subordination, exploitation, and animalization in the service of coloniality. While the results show specificities, primarily due to the COVID-19 pandemic, we found that algorithmic coloniality becomes apparent in these banks, which frequently tag the images of black women under colonial representation standards of labor, sexuality, and aggressiveness.

\section{Keywords (Source: Unesco Thesaurus)}

Coloniality; algorithms; black women; women of African descent; race; image banks. 


\section{Introdução}

Em meio à euforia trazida pelas possibilidades das tecnologias digitais, sobretudo no que tange ao desenvolvimento de cidades inteligentes (Lemos, 2013; Weiss, Bernardes e Consoni, 2017), à educação a distância a partir de realidade aumentada (Tori, 2018), à hipersegmentação em dinâmicas de consumo (Lima e Calazans, 2013), assim como a culturas que se formam a partir de aparatos móveis (Lemos, 2009; Da Silva, 2007), pesquisadores tentam expor o caráter nefasto e, muitas vezes, escondido dessas tecnologias, que podem reproduzir e reforçar desigualdades e violências sociais.

Pesquisas, portanto, buscaram compreender de que forma artifícios tecnológicos contemporâneos, como chatbots, mecanismos de busca e sistemas de reconhecimento facial baseados em inteligência artificial, podem ser geodiscriminatórios (Cesar Guimarães, 2019), racistas (Silva, 2020; Carrera e Carvalho, 2020; Noble, 2018; Birhane, 2020) e sexistas (Aiello e Woodhouse, 2016; Buolamwini e Gebru, 2018). Este trabalho, então, faz parte desse grupo de estudos, tentando identificar os vieses discriminatórios quanto a mulheres negras em fotografias de bancos de imagens. Fundamentais para o todo comunicacional contemporâneo ao ofertarem material imagético para mensagens postas em circulação por empresas, jornais e governos, esses bancos são atores potentes na construção dos signos sociais a respeito dos corpos e dos sujeitos sociais (Frosh, 2001).

Nesse sentido, parte-se do pressuposto de que os estereótipos circulantes sobre mulheres negras diferem significativamente daqueles que são atribuídos às mulheres brancas. Enquanto há sentidos de fragilidade, pureza e delicadeza no corpo feminino branco (Goffman, 1979), mulheres negras são associadas à força física e à animalização (Baker, 2005), assim como relegadas ao preterimento afetivo (Souza, 2008; Pacheco, 2008), em um processo de contínua mentalidade colonial que fixa corpos negros em lugares de subalternidade (Araújo, 2006). Dentro dessa perspectiva, entende-se que os padrões imagéticos em geral associados à mulher negra se resumem às "imagens de controle" pensadas por Collins (2002), aqui destacadas pela "Mammy", "Jezebel" e "Sapphire”. Nesse sentido, "Jezebel" seria a representação da mulher negra sexualmente disponível, animalesca; "Mammy" 
seria a representação da mulher negra empregada doméstica, que cuida dos filhos da família branca em detrimento dos laços com a própria família e que, comumente, é rejeitada afetivamente pelo parceiro; "Sapphire", a imagem de mulher dominante e agressiva, ameaçando os homens em seus sentidos de masculinidade. Assim, intenta-se aqui questionar se é possível perceber essas imagens de controle nos contextos contemporâneos das materialidades digitais.

Neste trabalho, portanto, busca-se comparar as representações de mulheres negras e brancas em bancos de imagens digitais (representados aqui pelo Getty Images e pelo Shutterstock), com o intuito de identificar se há diferenças nos resultados de busca apresentados pelos seus algoritmos. Aqui, são analisadas de forma exploratória mais de 2900 imagens às quais esses bancos atribuem relevância no contexto dos construtos "mulher negra" e "mulher branca", buscando responder se são as mulheres negras mais associadas à agressividade do que mulheres brancas (Sapphire). Se há, ainda, a atribuição do estereótipo da empregada doméstica, babá dos filhos de família branca (Mammy). E se as mulheres negras ainda são representadas como mais promíscuas e hipersexualizadas em comparação com mulheres brancas (Jezebel).

Discute-se, portanto, esses resultados sob a luz de teóricas brasileiras, como Sueli Carneiro (2003) e sua perspectiva atrelada ao feminismo negro, assim como Lélia Gonzalez (1988), Luiza Bairros (1995) e Carla Akotirene (2019), com seus pressupostos interseccionais sobre as opressões de gênero e raça. A partir desses vieses teórico-metodológicos, este artigo busca compreender os limites culturais e sociais de gênero e raça que permeiam a vida das mulheres negras, compreendendo que ainda circulam discursos coloniais - reforçados pelas imagens disponíveis nesses mecanismos de busca - sobre a existência do corpo negro e feminino. Ademais, são mobilizados pressupostos contemporâneos sobre aparatos de inteligência artificial da atualidade que, muitas vezes percebidos como neutros e objetivos, podem ser agentes vigorosos de reforço a sistemas de opressão, ajudando a construir e fundamentar as estruturas da desigualdade social e da colonialidade. 


\section{Colonialidade algorítmica e bancos de imagens}

$\mathrm{Na}$ dimensão tecnológica, parte-se da premissa pouco entusiasta a respeito dos artefatos disponíveis atualmente, sobretudo pelo reconhecimento dos "danos da categorização" (Birhane e Cummins, 2019, p. 1), comuns na inteligência artificial. Compreendendo que indivíduos marginalizados são mais impactados negativamente por decisões automatizadas e treinamento algorítmicos enviesados, já foi evidenciado como mecanismos de busca podem associar mulheres negras à pornografia (Noble, 2018), ferramentas de automação podem manter e reforçar desigualdades sociais (Eubanks, 2018), assim como tecnologias de reconhecimento facial podem aprofundar processos de exclusão em gênero e raça (Buolamwini e Gebru, 2018).

Assim, os pressupostos fundamentais dos estudos aqui presentes residem na não neutralidade algorítmica (Benjamin, 2019), na opacidade tecnológica (Silva, 2020) e nos vieses inerentes à inteligência artificial (Osoba e Welser IV, 2017). Especialmente nas dimensões raciais, vive-se, como explicado pela pesquisadora Ruha Benjamin, um novo "Jim code", uma vez que há emprego de tecnologias contemporâneas para reproduzir dinâmicas antigas de exclusão racial: "the employment of new technologies that reflect and reproduce existing inequities but that are promoted and perceived as more objective or progressive than the discriminatory systems of a previous era" (Benjamin, 2019, p. 11).

Entende-se, então, a existência de "dupla opacidade" (Silva, 2019) na constituição desses aparatos, já que a discriminação racial é resultado tanto do desconhecimento acerca da potência das desigualdades raciais, impregnadas nas ações e nos comportamentos de codificação, quanto da inexistência de etapas de esforço ético imbricadas nos processos de produção dessas ferramentas. Nesse sentido, algumas dessas práticas, por apresentarem caráter sutil que invisibiliza sua potência nociva, empreendem "microagressões codificadas", ou seja, modos encobertos de reforçar ofensas raciais tão violentas quanto racismo explícito (Silva, 2020).

2 "O emprego de novas tecnologias que refletem e reproduzem as desigualdades existentes, mas que são promovidas e percebidas como mais objetivas ou progressivas do que os sistemas discriminatórios de uma época anterior” (tradução nossa). 
Aliás, não somente essas tecnologias podem reproduzir opressões já estabelecidas em estruturas sociais anteriores, quanto armazenar e gerenciar dados sobre indivíduos de forma pouco transparente ou democrática. $\mathrm{Ou}$ seja, são informações sobre sujeitos e grupos sociais sob o controle de poucas empresas e indivíduos com interesses voltados à lucratividade. Nesse sentido, muitas vezes a lógica discriminatória imbricada nesses dispositivos serve à eficiência capitalista, que esvazia "possibilidades de resistências e projetos alternativos de sociedade que não passem, em certa medida, pela circulação do capital e por mecanismos de racionalidade neoliberal" (Grohmann, 2020, p. 116), isto é, aos moldes do pensamento colonial.

Nesse sentido, pode-se reconhecer os modos de produção e circulação das tecnologias digitais contemporâneas a partir da perspectiva da colonialidade (Quijano, 2002). Se a noção de colonialismo demarca sua temporalidade em práticas de dominação territorial e política, a colonialidade é a sobrevivência dos sentidos, das práticas e dos discursos de dominação que se imbricam nas materialidades culturais e nos comportamentos dos sujeitos sociais, ou seja, é a continuidade do discurso colonial escondido pelos véus legítimos da democracia. Assim, é fundamento principal da colonialidade a persistência da exploração de determinados corpos, sujeitos e lugares a serviço de outros, sobretudo sob a justificativa da razão, civilização e progresso (Bernardino-Costa e Grosfoguel, 2016). O corpo negro, portanto, vê continuada sua posição de colonizado, como um repositório de representações fixas em prol da construção de soberania branca (Mbembe, 2016).

Dentro dessa perspectiva, entendendo a dinâmica algorítmica contemporânea como envolta em princípios de colonialidade, autores como Birhane (2020), Astobiza (2017) e Mohamed, Png e Isaac (2020) alertam para a necessária implicação ética das tecnologias de automação, com vistas a reconhecer, apontar e questionar os padrões classificatórios e de comportamento de máquina que reproduzem lógicas de exploração. Nesse sentido, é evidente a lógica colonizatória imbricada nesses artefatos, que pressupõem sistemas de poder que "generate new labour markets, impact geopolitical power dynamics, and influence ethics discourse" (Mohamed et al., 2020, 
p. 7), impondo um processo de dominação "não por força física bruta, mas por mecanismos invisíveis e diferenciados de controle do ecossistema digital e da infraestrutura digital” (Birhane, 2020, p. 157). Vê-se, portanto, a reprodução do objetivo colonial em novos aparatos técnicos, "tendo como base uma origem racial para justificar a conquista e estabelecer sistemas administrativos e culturais" (Bhabha, 1992, p. 184).

Em bancos de imagens, especificamente, essa estrutura de poder colonial se manifesta na precisão falha da representação de alguns grupos sociais, mas também, no apagamento de indivíduos em alguns contextos de significação e na superexposição em outros. Os estereótipos raciais, portanto, servem como construtos simbólicos para a manutenção do poder branco e do lugar de subalternidade reservado aos sujeitos negros, isto é, não há força de soberania sem a marcação da ameaça que representa "o outro” (Bhabha, 1992). Mulheres negras, então, na lógica da opressão interseccional (Crenshaw, 2016), são esse outro racializado e sexualizado a partir da visão do sujeito branco masculino, que detém o poder sobre as lógicas de produção desses bancos (Frosh, 2001) e toda a engrenagem comunicacional e midiática.

Dessa forma, entender esses bancos de imagem como tecnologias racistas e sexistas é percebê-los sob o regime da colonialidade tecnológica, expondo sua não neutralidade e seus processos contínuos de algoritmização de desigualdades cristalizadas em outras conjunturas socioculturais. Esses mecanismos digitais de busca, por meio de seus processos de tagueamento de imagens e atribuição de relevância, além de promoverem o apagamento e a superexposição de sujeitos a partir de recortes raciais e de gênero, também inserem modos específicos de produção de significados enviesados, sobretudo com usos frequentes de estereótipos nocivos, narrativas desiguais e discriminatórias, bem como hiper-ritualizações de comportamentos culturalmente determinados (Goffman, 1979).

Enquanto mecanismos digitais de busca, esses bancos funcionam por meio de palavras-chave, armazenando e disponibilizando fotografias, ilustrações e vetores para incontáveis produções imagéticas, ou seja, é possí- 
vel pesquisar por imagens de pessoas, individualmente ou em grupo, em ambiente de trabalho, na conjuntura familiar, social, em lazer etc. Embora, portanto, o contexto de programação atrelado a esses bancos seja mais simplificado do que aqueles em mecanismos de busca que entregam sites como resultado (como o Google), há também uma fórmula algorítmica que define, dentro do seu acervo, quais imagens se relacionam a determinadas palavras-chave. Esses algoritmos, então, são produto de uma negociação entre os fotógrafos que disponibilizam suas imagens no banco, os gestores e os programadores do banco de imagem, sobretudo em atendimento às demandas de consumo de imagem da época ${ }^{3}$.

Assim, esses bancos recorrem a minuciosos processos de etiquetagem e seleção ${ }^{4}$, acompanhando a associação das palavras-chave às imagens ofertadas em seu acervo, assim como pela atribuição de relevância a alguns resultados em relação a outros, seja por popularidade, seja por semântica. No entanto, ao não deixarem claro o funcionamento dos seus algoritmos, reforçam a "dupla opacidade" (Silva, 2019, p. 4) na sua materialidade tecnológica, já que adicionam, inevitavelmente, valores a decisões automatizadas e não são transparentes a respeito das dinâmicas que influenciam suas decisões. Nesse sentido, embora componham universo tecnológico atualizado, fortalecendo as possibilidades de produção de conteúdo digital e offline, esses bancos parecem não disponibilizar representações adequadas às demandas da realidade social; ao contrário, podem ser agentes reforçadores de padrões coloniais, desigualdades e dinâmicas de opressão.

Com o objetivo, então, de identificar os lugares desses mecanismos nessa conjuntura, discutem-se aqui suas dinâmicas operacionais (aqui representados pelo Shutterstock e pelo Getty Images ${ }^{5}$ ) e seus treinamentos algorítmicos, suas dinâmicas de atribuição de relevância, bem como são analisados os resultados de busca na associação com padrões coloniais re-

3 Os bancos indicam imagens que podem ter mais popularidade, influenciando na contribuição dos fotógrafos-colaboradores, como o ShutterStock faz na página “Lista de conteúdo": https://www.shutterstock.com/pt/explore/the-shot-list

4 Os bancos deixam evidente que participam da seleção de todo o conteúdo disponibilizado, como pode ser visto na página "trabalhe conosco" do Getty Images: https://www.gettyimages.com.br/workwithus

5 Esses bancos foram escolhidos por representarem dois dos principais mecanismos de busca de imagens pagos da atualidade, sendo fonte imagética para comunicações circuladas globalmente. Disponíveis em:

https://www.shutterstock.com e https://www.gettyimages.com 
produzidos na contemporaneidade. Em trabalhos anteriores, foi possível perceber, por exemplo, que esses bancos reproduzem dinâmicas desiguais a respeito de profissão e renda (Carrera, 2020a); corroboram para legitimar o preterimento afetivo vivido pelas mulheres negras (Carrera e Carvalho, 2019), assim como aprofundam e fortalecem estereótipos afetivos e estéticos, quando atribuem agressividade e feiura ao corpo negro e gentileza e beleza ao corpo branco (Carrera, 2020b). Expondo, portanto, a opacidade algorítmica que não evidencia seus processos de construção de relevância de modo facilitado, entende-se a complexidade das dinâmicas produtivas desses repositórios de imagem, que são alimentados, sobretudo, por fotógrafos autônomos. Assim, pode-se questionar não somente os processos invisíveis de atribuição de relevância quanto os modos de etiquetagem (ou tagueamento), que se iniciam com os profissionais independentes, mas são validados e atestados pelos bancos, em um processo de intenso fortalecimento das opressões de gênero e raça na contemporaneidade. Mulheres negras, então, veem, nesses espaços, a consolidação das suas marginalizações impressas em soluções imagéticas, revivendo, a cada busca, os limites da sua subjetividade propostos pelo discurso colonial das tecnologias digitais.

\section{Jezebel, Mammy e Sapphire: imagens coloniais de controle para mulheres negras}

Bancos de imagens digitais podem ser compreendidos como outros espaços de "frustração da subjetividade" (Bueno, 2020) de mulheres negras, uma vez que potencializam o discurso colonial sobre seus corpos e cerceiam suas existências em narrativas fixas de desumanização. Nesse sentido, o debruçamento analítico sobre esses bancos e sobre as imagens disponíveis em seus acervos pode ser direcionado pela ferramenta conceitual "imagens de controle”, proposta por Patricia Hill Collins (2002), sob o entendimento de mulheres negras como uma categoria analítica necessária para pensar opressões interseccionais, como concebido no contexto brasileiro por Akotirene (2019) a partir dos estudos de Crenshaw (2016).

Carla Akotirene, uma das referências nos estudos feministas negros do Brasil, aponta para a especificidade das experiências de pessoas que intersectam "avenidas identitárias", isto é, que vivenciam cotidianamente as 
influências e as violências dos seus marcadores sociais da diferença ( $\mathrm{Sa}$ gesse et al., 2018). No Brasil, de acordo com a autora, é fundamental pensar a categoria social mulher, a partir dos pensamentos sobre construção de gênero, em contato com os modos de existência em uma cultura e uma sociedade historicamente racista. Nesse sentido, o conceito de interseccionalidade é substancial para a compreensão das identidades das quais "participa o racismo interceptado por outras estruturas" (Akotirene, 2019, p. 48). As imagens de controle, então, ajudam no entendimento desse cruzamento identitário que acomete mulheres negras: gênero e raça.

Collins pensa o conceito de imagens de controle como uma taxonomia dos modos discursivos em circulação sobre o corpo negro feminino, isto é, narrativas fixas e objetificadoras a respeito da mulher negra a serviço das práticas coloniais contemporâneas. São aparatos destinados a fazer desigualdades sociais, especialmente de raça, classe e gênero, parecer espontâneas, genuínas e irremediáveis. Assim, mais do que apenas estereótipos, imagens de controle são artifícios de poder, porque conservam premissas de subalternidade, necessidade de domesticação e controle, para um corpo marginalizado, visto como selvagem e ameaçador. Imagens de controle, portanto, agem em prol da grande "matriz de dominação" (Collins, 2002, p. 99) que subjuga corpos e sujeitos negros femininos.

Collins mapeia, então, imagens clássicas de controle, advindas do pensamento colonial, e suas mutações de acordo com a evolução histórica e cultural das narrativas sociais. Agressividade, servidão, hipersexualização e animalização permeiam essas definições e, de acordo com Collins (2002), fortalecem-se e se atualizam de acordo com as temporalidades e as conjunturas discursivas. Em bancos de imagem, esses modos de subjetivação são, então, reforçados e validados, sobretudo quando em comparação com as simbologias associadas às mulheres brancas. Neste trabalho, serão analisadas as imagens de controle Jezebel, Mammy e Sapphire.

A Jezebel reúne os atributos relacionados à hipersexualização da mulher negra, como corpo disponível ao acesso, sobretudo, do homem branco. Essa imagem de controle se fundamenta como justificativa colonial para 
a desumanização dos corpos negros e para a legitimação dos estupros do processo colonizatório (Carneiro, 1995; Davis, 2016; Woodard e Mastin, 2005), assim como, em contrapartida, auxilia no controle sexual também das mulheres brancas, uma vez que direciona os sentidos da "verdadeira feminilidade” para a pureza e a castidade (Collins, 2002). A Jezebel, portanto, é a sexualidade desviante, imoral e promíscua, que se coloca a serviço do olhar e do prazer alheio, isto é, em uma relação que não desloca o corpo negro feminino dos sentidos do trabalho (Gilliam, 1995).

No contexto brasileiro, os estudos de Luiza Bairros (1995), Lélia Gonzalez (1988) e Sueli Carneiro (1995) foram e são fundamentais para a compreensão dos modos de opressão vivenciados por mulheres negras, em um país que viveu processos de "miscigenação compulsória" (Nascimento, 1982, p. 27), com o embranquecimento como objetivo fundamental e a validação de violência sexual de homens brancos contra mulheres negras como etapa necessária e elementar. Nesse sentido, a imagem de controle da Jezebel é percebida aqui como uma continuidade desse padrão colonial e colonizatório, que considera pessoas negras como objetos a serviço do desejo sexual branco, mas mulheres negras, além disso, como disponíveis por opção e por sua constituição "natural”. Sueli Carneiro (1995, p. 546), dentro dessa perspectiva, aponta para a potência desse padrão subjetivo para a história e a constituição identitária do país: "o estupro colonial da mulher negra pelo homem branco no passado, e a miscigenação daí decorrente, criaram as bases para a fundação do mito da cordialidade e democracia racial brasileira”.

Nesse sentido, Jezebel é o contraponto da estereotipia feminina branca associada à fragilidade, delicadeza e pureza: "quando falamos do mito da fragilidade feminina, que justificou historicamente a proteção paternalista dos homens sobre as mulheres, de que mulheres estamos falando?” (Carneiro, 2003, p. 1). Nas imagens midiáticas e artísticas, a percepção do "toque feminino" delicado e gentil, que serve à exposição dos objetos, da face da mulher e do seu próprio corpo, em um ritual de subordinação e objetificação (Goffman, 1979), pertence apenas à feminilidade branca (Baker, 2005; Carneiro, 2003; Mclaughlin e Goulet, 1999). Isto é, se, às mulheres negras, são impostas performances de sexualidade agressivas, confiantes e 
atrevidas, a sensualidade das mulheres brancas se fundamenta pela timidez, vergonha e culpa.

Se a hipersexualização da mulher negra serve aos discursos da colonialidade e define o seu lugar em uma lógica de exploração do corpo, o seu contraponto também é útil ao sistema de dominação: a Mammy, que dialoga com a "mãe preta" no contexto brasileiro (Gonzalez, 1988), é assexuada, subserviente e dócil. A mammy, portanto, é a mulher negra presa ao serviço doméstico, aos cuidados da família branca e à lógica escravocrata do trabalho interminável e invisível. Enquanto mulher negra ideal, já que não se contrapõe diretamente ao sistema de subordinação a ela imposto, a mãe preta é um ser sem história, sem desejos e sem existência fora do contexto do trabalho em território branco: "a função desse estereótipo reside em negar o agenciamento das mulheres negras” (Cardoso, 2014, p. 975). Nesse sentido, "Mammy is the public face that Whites expect Black women to assume for them" (Collins, 2002, p. 73) ${ }^{6}$.

Assim, a figura da Mammy e a da mãe preta também se fundem à imagem da "ama de leite", figura recorrente em contextos coloniais: escravas a serviço do aleitamento de crianças brancas, nutrindo relações afetivas e carinhosas com aqueles que eram, mesmo enquanto crianças, donos de seus corpos e de suas ações. Em contextos contemporâneos e brasileiros, a Mammy pode ser a babá ou a empregada doméstica, já que a lógica da subordinação a partir do contexto familiar e afetivo, mesmo que sob os ditames violentos da precarização do trabalho, segue semelhante àquela pensada na conjuntura colonialista. São pessoas invisibilizadas, silenciadas e envoltas em expectativa de passividade, novamente expropriadas de seus próprios laços familiares em prol da manutenção da soberania branca. O corpo negro, portanto, constantemente relegado ao serviço doméstico em casas brancas, não parece poder existir em outro lugar, como lembra Audre Lorde (2003, p. 45): "recorro un supermercado con mi hija de dos años que va sentada en el carrito; una niñita blanca pasa [...] y dice muy excitada: 'Mira, mamá,juna criada bebé!’”.

6 “Mammy é a face pública que brancos esperam que mulheres negras assumam para eles" (tradução nossa). 
A imagem de controle Sapphire, constantemente apresentada em narrativas midiáticas (West, 1995), é o oposto da Mammy, uma vez que se caracteriza pela agressividade, pela prepotência, pela assertividade e pela expansividade exageradas. A Sapphire seria castradora das masculinidades, pelo seu caráter dominante e indiscreto, portanto comumente preterida para relações românticas. Considerando que seu predicado fundamental é a capacidade de responder às pessoas de forma altiva e provocadora (Jewell, 1993), Sapphire é mais uma imagem negativa da mulher negra para a branquitude, uma vez que a ameaça em seu poder de dominação. Ademais, se o ideal de feminilidade branca é a passividade, reserva e quietude (ReynoldsDobbs, Thomas e Harrison, 2008), Sapphire, sendo hostil, falante e rude, é o estereótipo necessário para manter o silenciamento de todas as mulheres.

Nesse sentido, a imagem da Sapphire é o polo contrário da ritualização de comportamento feminino idealizado na atualidade ocidental, perturbando o poder masculino com sua assertividade. Sapphire, então, é a forma clássica da contemporânea "black lady" de Collins (2002), justificando, inclusive, o preterimento afetivo comumente vivenciado por mulheres negras: "Highly educated Black ladies are deemed to be too assertive - that's why they cannot get men to marry them" (Collins, 2002, p. 81). Em imagens midiatizadas, portanto, a diferença entre os posicionamentos corporais de mulheres brancas e negras pode ser extremamente ampliada, uma vez que rituais de subordinação de gênero comuns a mulheres brancas, como dobrar o joelho, inclinar a cabeça e olhar para fora da câmera, sinalizando timidez, vergonha e desorientação (Goffman, 1979), podem ser substituídos por olhares diretos e impositivos, braços cruzados, seriedade e altivez no contexto da representação da mulher negra (McLaughlin e Goulet, 1999); assim como mulheres negras são representadas mais comumente sozinhas, em comparação ao núcleo familiar tradicional ao contexto branco (Baker, 2005; Goffman, 1979).

Embora Collins (2002) identifique outras imagens de controle, como a Welfare Mother, a Hoochie e a Matriarch, debruça-se aqui sobre Sapphire,

7 "Mulheres negras altamente educadas são consideradas demasiado assertivas — é por isso que não conseguem que os homens se casem com elas" (tradução nossa). 
Jezebel e Mammy como recorte teórico-metodológico, porque essas imagens compõem com frequência o discurso colonial reproduzido em narrativas midiáticas e comunicacionais (Givens e Monahan, 2005). Nesse sentido, esse universo de significações atribuído ao corpo negro feminino é diluído em diversos modos de construção imagética em circulação. Em bancos de imagens, a colonialidade algorítmica que fixa mulheres negras em sentidos de subordinação se manifesta, portanto, em vários pontos das suas lógicas de funcionamento, com destaque para a atribuição de relevância e para os processos enviesados de etiquetagem de palavras-chave.

\section{Delineamentos metodológicos}

A análise empreendida aqui é exploratória, com o objetivo de definir padrões de representação encontrados em bancos de imagens. Nesse sentido, o interesse primordial não está na quantificação da representação, mas nos modos de reprodução do discurso colonial em processos de tagueamento. No entanto, em algumas etapas da análise, são apresentados dados quantitativos como forma de expor silenciamentos ou superexposições de grupos sociais, sob o recorte de gênero e raça, em determinados contextos imagéticos. Foram analisados os bancos de imagens Shutterstock e Getty Images, com as palavras-chave "black woman" e "white woman", assim como "nanny" e "babá", aliando aos resultados encontrados em trabalhos anteriores a respeito das palavras-chave "aggressiveness" e "beauty" (Carrera, 2020b).

Uma vez que o intuito do trabalho é perceber se há reprodução dos padrões coloniais associados a mulheres negras a partir das imagens de controle Jezebel, Mammy e Sapphire, a escolha das palavras-chave se deu a partir das possibilidades de resultado dentro do contexto semântico desejado. Ou seja, no caso dos padrões Jezebel e Sapphire, as palavras-chave "black woman" e "white woman" contemplam a generalização dessas imagens de controle, que atribuem as características de disponibilidade sexual e agressividade à subjetividade e aos comportamentos da mulher negra em qualquer ambiente. No entanto, a imagem de controle Mammy está relacionada diretamente ao contexto doméstico e de cuidado. Nesse sentido, sobretudo no contexto brasileiro, como apontado por Carneiro (2003) e Gonzalez (1988), babás e empregadas domésticas seriam a reprodução 
contemporânea das "mães pretas", uma vez que se configuram majoritariamente por mulheres negras em uma conjuntura colonial e servil em prol de famílias brancas. Assim, para entender essa reprodução em bancos de imagem, optou-se por analisar as palavras-chave "babá" e "nanny".

Optou-se aqui pelo uso do inglês na pesquisa das palavras-chave, pois este estudo faz parte de projeto ampliado de pesquisa sobre bancos de imagens, sendo relevante padronizar os modos de análise ${ }^{8}$. No entanto, pôde-se perceber que não há diferenças significativas na maioria das palavras-chave e suas traduções, como em "black woman" /"mulher negra" e "white woman"/"mulher branca", mas houve resultados diferenciados para "nanny” e sua tradução no contexto brasileiro para "babá” em um dos bancos. Assim, optou-se aqui por considerar os dois resultados. Por sua vez, a pesquisa por palavras combinadas, como black + woman e white + woman, apresentou diferenças relevantes daquela com aspas ("blackwoman" e "white woman"). Optou-se aqui, portanto, por manter os dois resultados e identificar suas especificidades.

Foram analisados os resultados das três primeiras páginas de busca, em cada palavra-chave. Não foram aplicados filtros específicos, uma vez que o objetivo da pesquisa é apresentar os resultados gerais encontrados nesses bancos. Nesse sentido, foi utilizado o processo de pesquisa-padrão dos sites, que consiste em expor todas as imagens (fotografias, ilustrações, vetores, imagens artísticas e editoriais), com o filtro da relevância (isto é, resultados considerados, pelo algoritmo, mais pertinentes à busca), assim como as tags associadas às imagens, que são atribuição inicial dos fotógrafos, mas são corroboradas, revisadas e finalizadas pelos bancos. A intenção desta análise é perceber que não somente esses bancos oferecem uma classificação de relevância que deve ser questionada (sendo responsáveis pelos produtos imagéticos e pela codificação do seu espaço), como também as escolhas de montagem e etiquetagem dessas imagens também podem empregar dinâmicas racistas e sexistas, em um processo de alimentação e retroalimentação da opressão de gênero e raça.

8 A questão de marcação de gênero na língua portuguesa poderia dificultar as análises de algumas palavras-chave relevantes para a pesquisa. 
As pesquisas de palavras-chave foram realizadas em agosto, setembro e outubro de 2020, como forma de testar se houve alguma atualização nos resultados'. No entanto, não foram identificadas alterações nos resultados nesse período. O Shutterstock apresenta, em seu filtro-padrão, mais imagens em cada página de resultado do que o Getty Images, em virtude do tamanho da exposição. No contexto da palavra-chave "black woman", a pesquisa no Shutterstock resultou, nas suas três primeiras páginas de resultados, em 313 imagens; as palavras combinadas "black" + "woman" resultaram em 319 imagens. No caso do Getty Images, a palavra-chave "black woman" resultou, nas suas três primeiras páginas, em 174 imagens; as palavras combinadas "black" + "woman" resultaram em 181 imagens.

No contexto branco, Shutterstock resultou em 318 imagens para white woman e 312 imagens para white + woman. Já o Getty Images apresentou 179 imagens para white woman e 178 imagens para white + woman. Assim, nesse contexto de palavras-chave associadas diretamente às mulheres negras e brancas, foram analisadas no total 1974 imagens. Já a palavra-chave "nanny" e sua tradução "babá" apresentaram especificidades em cada banco de imagens. No Getty Images, "nanny" e "babá" apresentam resultados idênticos, no entanto, no Shutterstock, os resultados são expressamente diferenciados. Optou-se por identificar essas diferenças, pois pareceram relevantes para a análise aqui empreendida dos sentidos associados ao corpo negro feminino. No Getty Images, portanto, "nanny" e sua tradução "babá" resultaram nas mesmas imagens: 181 resultados para cada uma das pesquisas. A análise, então, foi duplicada. No Shutterstock, a pesquisa por "nanny" resultou em 306 imagens nas três primeiras páginas de resultados; em "babá", foram encontradas 308 imagens. Assim, ao todo, foram analisadas 2950 imagens para a pesquisa aqui proposta, combinadas com resultados de trabalhos anteriores.

9 Embora não seja objetivo principal do trabalho identificar alterações sazonais, a percepção de estabilidade ou flutuação da atribuição de relevância às palavras-chave poderia dar pistas dos fatores que influenciam na lógica algorítmica do banco de imagens. Nesse caso, as demandas mensais não foram suficientes para qualquer alteração, embora a pandemia da covid-19 tenha influenciado de forma mais potente em todos os meses. 


\section{Sapphire: mulheres negras e associação à agressividade}

Em trabalhos anteriores, a pesquisa pela palavra-chave "aggressiveness" mostrou que a agressividade é um construto associado à masculinidade. No entanto, pôde-se perceber que, embora representem a minoria nesses resultados, as mulheres que aparecem estão posicionadas como vítimas da agressividade e não como agentes da ação agressiva. Isto é, no contexto imagético, o posicionamento corporal das mulheres, em associação com aquele atribuído aos homens, constrói estes como agentes e elas, como destinatárias. São comuns, portanto, imagens com mulheres e rostos machucados; homens encurralando mulheres em paredes ou grades; homens em posição de golpes direcionados a mulheres; homens direcionando gritos a mulheres (Carrera, 2020b). Contudo, a análise interseccional, que prevê a raça como categoria fundamental em pesquisas de gênero (Crenshaw, 2016; Akotirene, 2019), mostra que esses resultados são específicos para o contexto branco. As mulheres negras que surgem nesse resultado, ao contrário, representam, em sua maioria, o sujeito da ação agressiva, e não aquele que é vitimado por ela.

Em combinação com esses resultados, os estudos das palavras-chave "black woman" e "white woman" revelaram sentidos semelhantes. Nessas imagens, foram analisadas as posturas das mulheres brancas e negras, buscando identificar se mulheres negras são mais colocadas em posição de seriedade e assertividade do que mulheres brancas. Assim, representações coerentes com a imagem de controle Sapphire são aquelas que posicionam a mulher séria, com punho fechado, braços cruzados, com olhar direto e impositivo para a câmera, sem traços de timidez ou desorientação, como aqueles associados às mulheres brancas (Goffman, 1979). Aqui, imagens com dois ou mais códigos associados à Sapphire foram consideradas como representativas dessa imagem de controle. Optou-se por excluir algumas imagens mesmo quando apresentavam seriedade, porque associavam esse código à timidez (quando a mulher olha para baixo), assim como à concentração (mulher séria olhando para telas de computador, celular etc.). Braço cruzado e olhar direto, mesmo combinados, quando associados à expressão de sorriso e alegria, também não reúnem significados coerentes com a ideia 
de agressividade. Nesses casos, as imagens não foram consideradas como coerentes com a imagem da Sapphire.

No Getty Images, interessante notar que black woman resultou em muitas imagens de mulheres negras utilizando máscara, o que evidenciou a variabilidade da atribuição de relevância no algoritmo, que prevê a popularidade das imagens a partir das conjunturas sócio-históricas. Nesse sentido, as imagens seguiram a necessidade de representar o contexto da pandemia da covid-19, embora essa preocupação não tenha sido reproduzida em bla$c k+$ woman ou no contexto branco. Somados, os resultados para black woman e black + woman apresentaram 39 imagens coerentes com a Sapphire, isto é, $10,98 \%$ da sua totalidade. No contexto branco, interessante notar que a pesquisa por white woman apresentou imagens diferenciadas do ethos publicitário comum nesses bancos (Frosh, 2001), mas um tom editorial mais evidente, parecendo mostrar uma fuga algorítmica da objetificação feminina. No entanto, white + woman volta a apresentar imagens mais coerentes com aquelas de tom comercial. Descartadas essas especificidades, da totalidade dos resultados encontrados, apenas 5, isto é, 1,4\% foram coerentes com a imagem da Sapphire.

No Shutterstock, o uso de aspas ou da combinação de palavras-chave não fez muita diferença nos resultados disponibilizados pelo banco. Black woman e black + woman, assim como white woman e white + woman apresentaram resultados quase idênticos. No entanto, prevendo algumas imagens diferenciadas, decidiu-se somar os resultados, entendendo-os como pesquisas diversas. Somados, os resultados para black woman e black + woman apresentaram 67 imagens coerentes com a Sapphire, isto é, 10,60\% da sua totalidade. No contexto branco, da totalidade dos resultados encontrados, 59, isto é, 9,36 \% foram coerentes com a imagem da Sapphire.

Nesse sentido, a combinação dos resultados dos dois bancos de imagens (ver figura 1) comprova o aumento dos signos da imagem de controle Sapphire às mulheres negras, revelando que ainda há, em comparação com mulheres brancas, a preservação do imaginário colonial sobre a subjetividade feminina. Em adição aos resultados para a palavra-chave "aggressiveness", 
pode-se perceber que esses bancos e seus processos de tagueamento produzem algoritmização das opressões cristalizadas de gênero e raça que incidem sobre o corpo negro feminino e que delimitam os sentidos possíveis da sua existência (Bairros, 1995).

\section{Figura 1. Exemplo de posicionamentos coerentes com a imagem de controle Sapphire. Contexto hospitalar e máscaras aparecem com muita frequência}

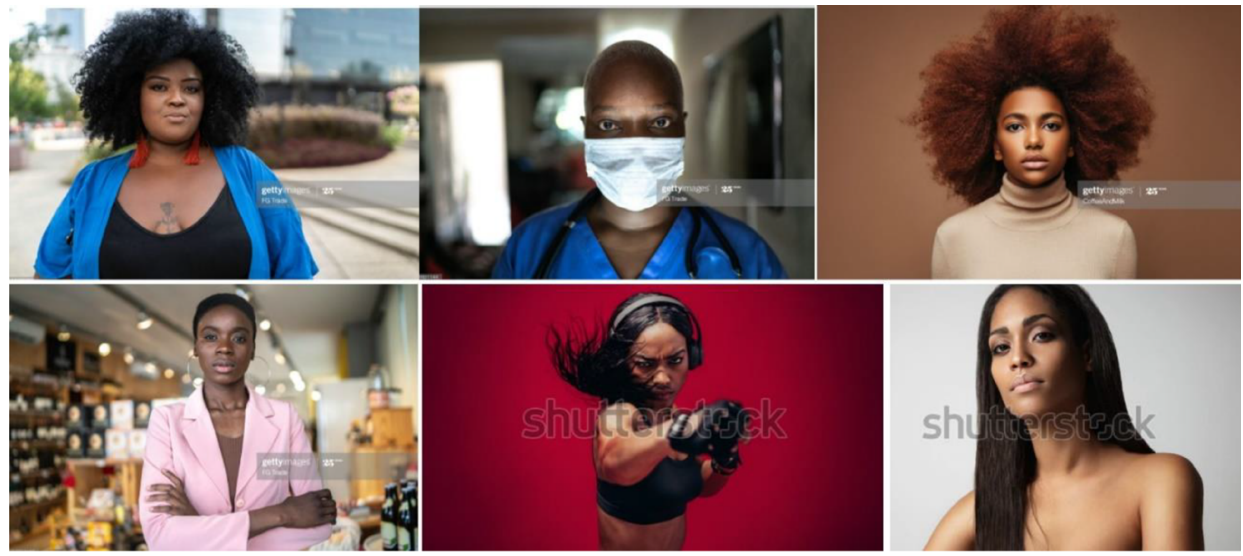

Fonte: Getty Images e Shutterstock.

\section{Mammy: mulheres negras e herança colonial de subordinação}

Com o objetivo de entender se a figura da mammy pode ser perceptível no contexto dos bancos de imagem como imagem de controle da mulher negra, optou-se aqui por analisar os resultados das palavras-chave "nanny" e "babá". Entende-se o trabalho doméstico como remanescente do projeto colonial, sendo composto, no Brasil, por maioria de mulheres negras, de baixa escolaridade (Pinheiro, Lira, Rezende e Fontoura, 2019). Se, em 2014, $70 \%$ trabalhavam na informalidade, sem direito à carteira assinada ou salário-mínimo (Vieira e Almeida, 2019), com a Emenda Constitucional 72/2013 e a Lei Complementar 150/2015, seus direitos começaram a ser ampliados, mas a colonialidade atribuída à prática profissional e aos corpos submetidos a ela persistiu em considerá-las sob subalternidade e exploração. Embora o amparo legal tenha sido importante, nesses primeiros 
anos, para o pequeno crescimento de trabalhadoras com carteira assinada, em 2018, já "voltamos novamente a patamares inferiores aos $30 \%$ e apenas $28,6 \%$ das trabalhadoras domésticas estavam protegidas socialmente desta forma" (Pinheiro et al., 2019). Nesse sentido, resta, na contemporaneidade brasileira, uma lógica trabalhista semelhante àquela possível na ocasião do fim da escravidão: sem opção, o trabalho doméstico surge como única saída para a sobrevivência, mesmo que implique situações diárias de precariedade e humilhação (Bernardino-Costa, 2007).

As babás, assim como as empregadas domésticas, portanto, participam do ambiente familiar branco como mulheres negras em narrativas "que vão do afeto à abjeção” (Vieira e Almeida, 2019, p. 149). São as babás, na cultura contemporânea, as representações ideais da mammy ou da mãe preta, uma vez que "é o corpo da babá que faz dengo, dá bronca, protege e ensina, bem como é esse mesmo corpo rejeitado em alguns ambientes da casa e evoca nojo aos adultos se o cabelo crespo está solto" (Vieira e Almeida, 2019, p. 149). A negritude está, portanto, vinculada à figura da babá, assim como a todos os signos de negatividade que são associados aos dois construtos.

Nas pesquisas pelas palavras-chave "nanny" e "babá", nos dois bancos de imagens aqui analisados, os resultados são coerentes com essa conjuntura racial, uma vez que quebram a escassez do corpo negro como resultados nestes bancos ${ }^{10}$. A associação do corpo negro feminino à figura da trabalhadora doméstica se manifestou quantitativamente. No Getty Images, os resultados para nanny e babá foram quase idênticos. Prevendo algumas imagens diferenciadas, decidiu-se somar os resultados, entendendo-os como pesquisas diversas (181 para nanny e 181 para babá). No Shutterstock, houve diferenças significativas entre os resultados para nanny e resultados para babá. Foram 306 para nanny e 308 para babá. No contexto desta pesquisa, foi analisada a quantidade de mulheres brancas com crianças brancas; mulheres negras com crianças brancas; mulheres brancas com crianças negras e mulheres negras com crianças negras.

10 Mulheres e homens negros são minoria em quase todos os resultados de busca nesses bancos de imagens. A exclusão desse grupo racial nas imagens já seria uma problemática relevante, mas é importante perceber, para além desse apagamento, de que modo são representados quando a exposição acontece. 
No Getty Images, das 362 imagens, 166 resultaram em mulheres brancas com crianças brancas $(45,85 \%)$, corroborando com a maioria dos resultados desses bancos, que vê a branquitude como ideal imagético (Frosh, 2001) em quase todos os contextos. No entanto, o segundo resultado relevante é de mulheres negras com crianças brancas, com 50 imagens $(13,81 \%)$, seguido de mulheres negras com crianças negras, com 10 imagens $(2,76 \%)$ e de mulheres brancas com crianças negras, com apenas três imagens $(0,8 \%)$. Foram desconsideradas imagens com outros grupos raciais, como aquelas que representavam mulheres asiáticas, assim como imagens que não permitiam a demarcação evidente da raça.

Interessante perceber que, no Getty Images, é possível conhecer as outras tags associadas à imagem em questão. Foi relevante notar que mulheres brancas com crianças brancas também são etiquetadas como "mães", no entanto as imagens de mulheres negras com crianças negras que surgem nesta pesquisa por babá/nanny não apresentam esse duplo tagueamento. Mulheres negras com crianças brancas também não apresentam essa dupla contextualização, sendo estritamente associadas a relações de trabalho. $\mathrm{Mu}$ lheres brancas com crianças negras são tagueadas também com palavras relacionadas a processos adotivos, como "orfanato" e "adoção" (ver figura 2). A associação restrita das possibilidades de sentido atribuído pelo tagueamento mostram, portanto, que se há direcionamentos fixos para mulheres negras, que sobretudo devem estar disponíveis para o cuidado da família branca, há o fortalecimento do "white savior complex" (Cole, 2012), já que não cogita a possibilidade de mulheres brancas atuarem em relação de subalternidade profissional a famílias negras.

No Shutterstock, as palavras-chave "nanny" e "babá” resultaram bem diferentes. Em nanny, das 306 imagens, 146 resultaram em mulheres brancas com crianças brancas $(47,71 \%)$, corroborando novamente com a branquitude como ideal imagético. $O$ segundo resultado relevante também é de mulheres negras com crianças brancas, com 19 imagens (6,20\%), seguido de mulheres negras com crianças negras, com cinco imagens $(1,63 \%)$ e de mulheres brancas com crianças negras, com apenas quatro imagens $(1,3 \%)$, das quais três semelhantes ao contexto escolar (quando há uma mulher 
adulta e diversas crianças, sendo uma delas negra). Nesse sentido, a quase inexistência de mulheres brancas, novamente, prestando serviço doméstico em favor de famílias negras deixa clara a "herança cultural" da expectativa branca de acesso ao poder (Sovik, 2009, p. 82), em uma construção de branquitude como superioridade absoluta (Schucman, 2014).

\section{Figura 2. Mulheres negras tagueadas como babás de crianças brancas; mulheres brancas tagueadas como babás de crianças negras apenas em contexto escolar; mulheres brancas não tagueadas como babás, mas como "adoção", quando sozinhas}

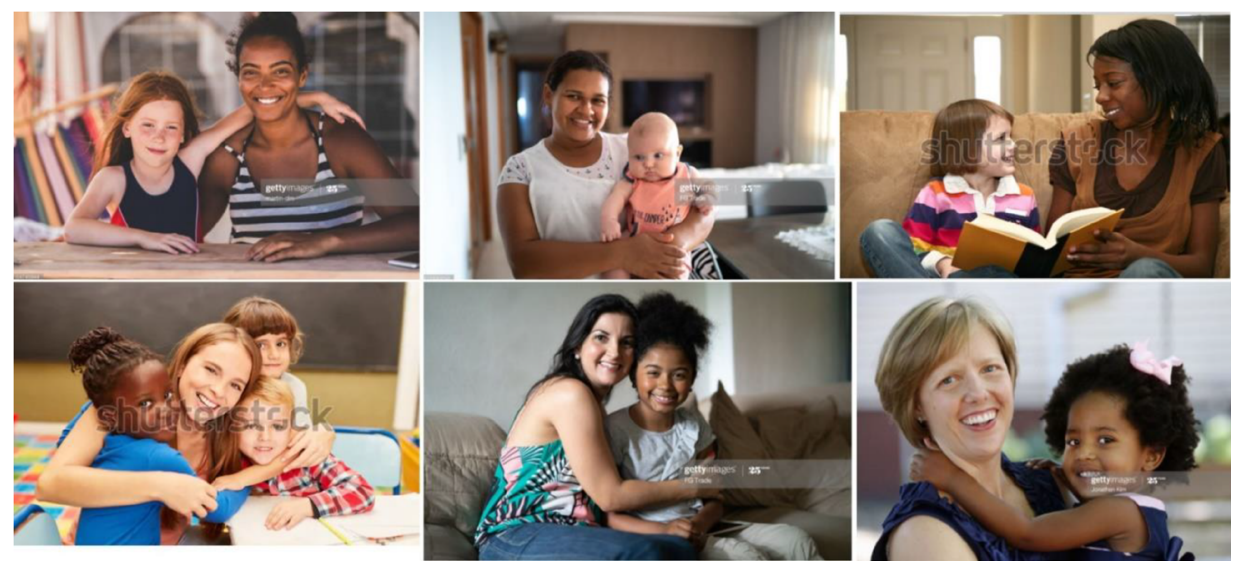

Fonte: Getty Images e Shutterstock.

Em babá, o Shutterstock deixa escapar os sentidos associados ao cargo, também condizentes com o discurso colonial que subjuga corpos femininos negros à disponibilidade laboral e sexual. Há sugestões de palavras-chave, como "casal sensual", "mulher sexy cama", "sexy woman oriental", "amor e sexo", "big ass", "fotos beijos" e "sex", em uma conexão direta da profissão de babá à sexualização, isto é, aparece "como uma mulher de quem se tem o direito de apropriação, inclusive do ponto de vista sexual, justamente por sua condição, a qual é descrita como de total submissão" (Corossacz, 2014, p. 536). Em termos quantitativos, interessante perceber que o Shutterstock parece confundir a figura da babá com agentes de saúde, sobretudo em contextos de pandemia da covid-19, trazendo como vasta maioria dos resulta- 
dos figuras de jaleco e máscara em contexto hospitalar. No entanto, aquelas condizentes com o serviço doméstico, em que compõem mulher e crianças, o banco segue lógica semelhante ao Getty Images: das 308 imagens coletadas, 13 são de mulheres brancas com crianças brancas $(4,22 \%)$; duas, de mulheres negras com crianças brancas $(0,64 \%)$; duas, de mulheres brancas com crianças negras, todas em contexto escolar (0,64\%); uma, de mulher negra com criança negra $(0,32 \%)$. A palavra "babá”, portanto, mesmo apresentando um comportamento algorítmico equivocado, mostra, a partir de seus resultados ínfimos, a representação da colonialidade.

\section{Figura 3. Termos sugeridos como associados à palavra-chave "babá"}

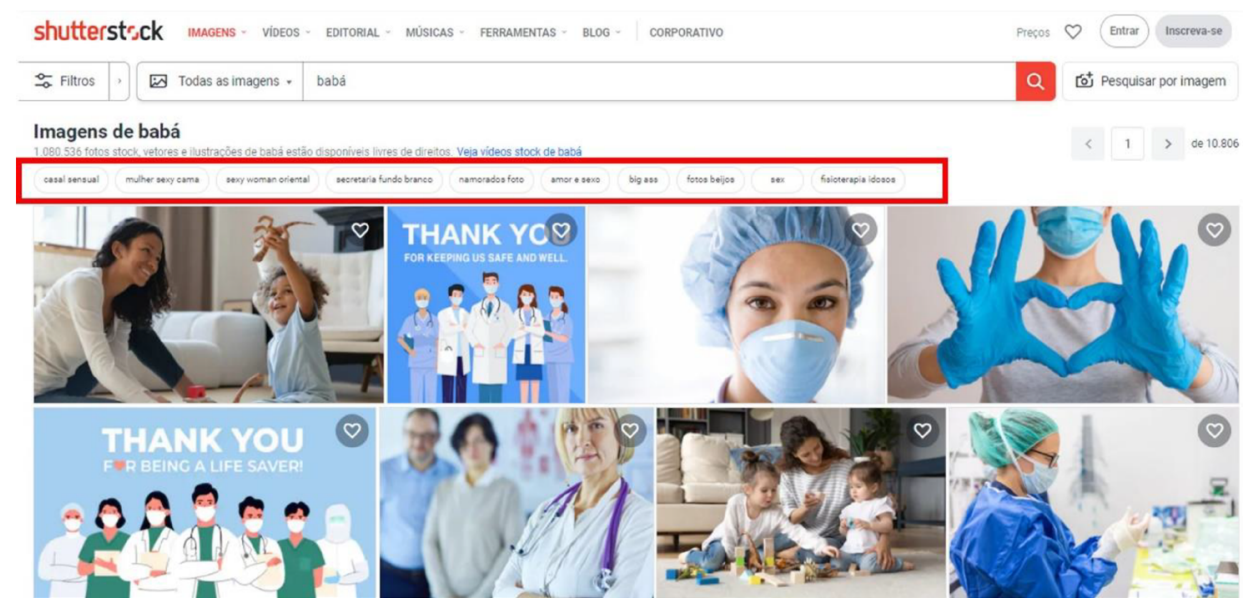

Fonte: Shutterstock.

\section{Jezebel e a hipersexualização da mulher negra}

Em trabalhos anteriores, foi possível perceber que, em bancos de imagem, a lógica da beleza feminina a serviço do olhar alheio, em um processo de objetificação, é comum a mulheres brancas e negras (Carrera, 2020b). No entanto, às mulheres brancas, é atribuída uma postura delicada, frágil e desorientada, isto é, com o "toque feminino" ideal: aquele que expõe seu corpo e sua face em um processo suave de objetificação (Goffman, 1979). A beleza das mulheres negras, ao contrário, é associada ao construto da disponibilidade, coerente com o discurso colonial de acesso irrestrito ao corpo negro feminino: sem desorientação, com assertividade e agressividade. 
Em combinação com esses resultados, optou-se por analisar a presença da imagem de controle da Jezebel a partir dos posicionamentos e dos contextos imagéticos encontrados em black woman/black + woman e white woman/white + woman. Aqui, corpos femininos com olhar direcionado para a câmera, sem ritualização de desorientação (Goffman, 1979); nudez sem signos de timidez, mas de exposição voluntária e explícita; corpos nus em contextos de natureza, combinados a animais, folhas e árvores (Plous e Neptune, 1997), assim como partes do corpo recortadas, como boca, seios e pernas, foram consideradas como coerentes com a imagem da Jezebel, uma vez que sugerem animalização, disponibilidade sexual e objetificação (Baker, 2005).

Nesse sentido, o Getty Images apresentou imagens bem diferenciadas do Shutterstock. No Getty Images, “black woman” resultou em apenas sete imagens coerentes com Jezebel, assim como três imagens em black + woman. Já "white woman" resultou em apenas duas imagens coerentes com Jezebel, assim como white + woman apresentou apenas quatro imagens nessas circunstâncias. Nesse sentido, raras imagens colocaram mulheres em objetificação sexual, estando a maioria, inclusive, representando o contexto da pandemia da covid-19 (muitas mulheres usando máscaras, mesmo fora do contexto hospitalar). Além da conjuntura sócio-histórica atípica, que pode influenciar na atribuição de relevância das imagens, o Getty Images parece ciente das discussões contemporâneas a respeito de gênero e raça, uma vez que recentemente lançou campanha de diversidade junto à Dove e declaração em favor do movimento "Black lives matter", reconhecendo a potência dos bancos de imagens como mediadores culturais (Frosh, 2001). Embora não haja declaração explícita a esse respeito, as palavras-chave "black woman" e "white woman" podem ter sido ajustadas de acordo com essa demanda. De qualquer forma, ainda assim, as imagens de mulheres negras em posições coerentes com Jezebel aparecem em maior quantidade que aquelas protagonizadas por mulheres brancas.

Essa percepção se justifica, ainda, pela diferença encontrada nos resultados do Shutterstock. Das 632 imagens no contexto de black woman, 112 resultaram coerentes com a imagem de controle da Jezebel, isto é, 
$17,72 \%$. Na pesquisa por white woman, das 630 imagens, apenas 34 eram coerentes com Jezebel, ou seja, 5,39\%. Além disso, a maioria das imagens que representavam mulheres brancas em processo de objetificação sexual, fora do contexto da Jezebel, apresentava sensualidade condizente com fragilidade, delicadeza e timidez, em consonância com trabalhos e perspectivas anteriores.

\section{Figura 4. Imagens coerentes com Jezebel}

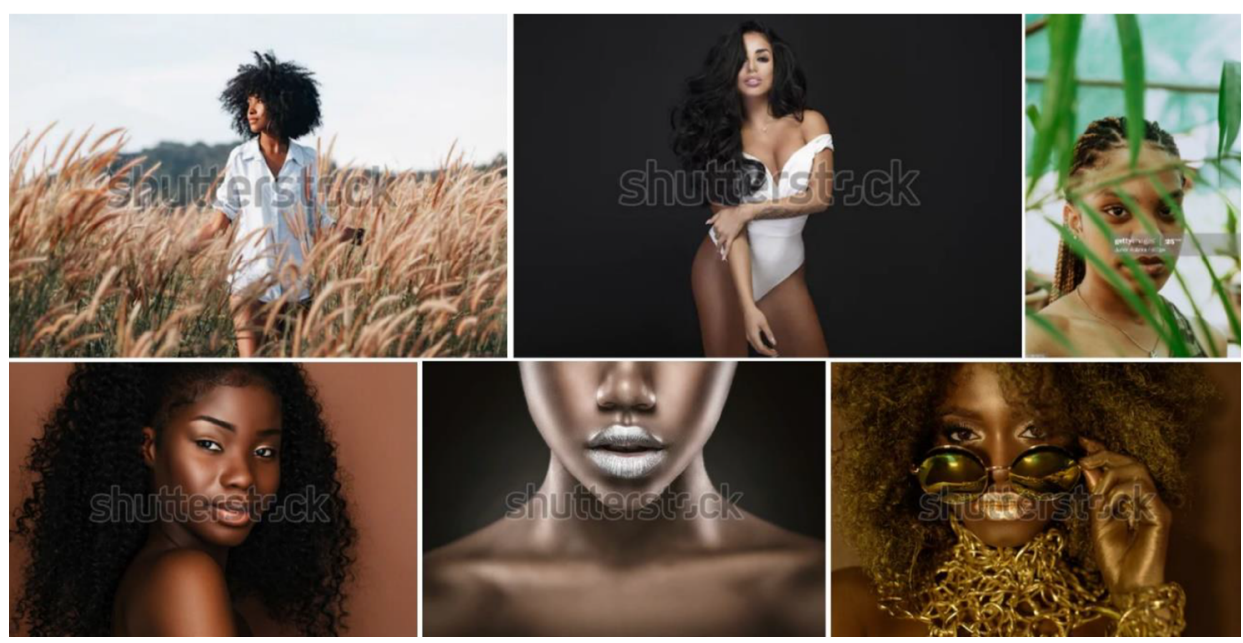

Fonte: Getty Images e Shutterstock.

\section{Conclusões}

Este trabalho partiu do conceito de "imagens de controle", de Patricia Hill Collins, para analisar padrões coloniais a respeito de mulheres negras em algoritmos de bancos de imagem. Entende-se aqui que mecanismos de busca e seus processos de atribuição de relevância podem ser agentes potentes de reforço a narrativas de desigualdades sociais em gênero e raça. Foram analisados os bancos de imagem Shutterstock e Getty Images, com as palavras-chave "black woman" e "white woman", assim como "nanny" e "babá", aliando aos resultados encontrados em trabalhos anteriores a respeito das palavras-chave "aggressiveness" e "beauty". Embora a pandemia da covid-19 tenha influenciado nos resultados, foi possível notar que, em comparação com mulheres brancas, mulheres negras são tagueadas mais frequentemente a narrativas de subordinação, que associam seus corpos a 
cargos de subalternidade a serviço de família branca (nanny/babá), coerentes com a imagem de controle Mammy; animalização e hipersexualização, condizentes com a imagem da Jezebel; assim como conectadas à agressividade, como a imagem de controle Sapphire.

É importante notar que esses repositórios de imagem costumam atribuir à branquitude o padrão imagético ideal, portanto a análise dos resultados de busca já considera que o contexto branco será majoritário. Nesse sentido, os estudos em banco de imagens precisam ir além da quantificação dos resultados e entendê-los a partir de comparações e contextualizações, sobretudo em relação aos sentidos imbricados discursivamente. Mais do que expor apagamentos e superexposições, este trabalho buscou identificar modos de colonialidade algorítmica que etiquetam mulheres negras como babás de crianças brancas, mas etiquetam mulheres brancas com crianças negras no termo "adoção", por exemplo.

Além disso, entender os processos de construção algorítmica e as dinâmicas de funcionamento desses bancos não é negligenciar a responsabilidade dos fotógrafos que os alimentam com suas imagens, mas reconhecer a potência desses espaços como lugares de reforço, produção e reprodução de narrativas desumanizadoras para mulheres negras. Fotógrafos, então, assim como são agentes de reprodução desses rituais de subordinação em seus materiais, também são afetados pelas imagens em circulação, em um processo complexo de reprodução discursiva a partir desses mediadores culturais. Sabe-se, inclusive, que esses bancos revisam, aprovam e atestam as tags sugeridas pelos profissionais, obtendo total responsabilidade pelo conteúdo que colocam à disposição.

Pôde-se perceber, além disso, que a popularidade das imagens, dimensão muitas vezes reivindicada como atributo essencial para a atribuição de relevância dos algoritmos desses bancos, é ajustada de acordo com a conjuntura sócio-histórica, uma vez que muitas pesquisas apresentaram sujeitos com máscara, em contextos hospitalares, em clara alusão à pandemia da covid-19. Nesse sentido, fica evidente que os bancos de imagens regulam seu acervo e o algoritmo que atribui relevância às imagens a partir 
de um fator contextual que definirá o fluxo da demanda de consumo. Nesse caso, a atual emergência sanitária determinou que as comunicações institucionais, governamentais e de marca se adequassem a esse contexto e apresentassem, em suas imagens, pessoas usando máscara tanto em contexto hospitalar quanto cotidiano. Os bancos, então, reconheceram a necessidade de ofertar esse tipo de representação. Se há, então, esse ajuste para atender à demanda de consumo, os processos de tagueamento, atribuição de relevância e produção de acervo poderiam ser também adaptados a partir das demandas sociais, inclusive, quando estas reivindicam ética, responsabilização e narrativas igualitárias.

Nesse sentido, este trabalho se junta a grupos de estudo e pesquisadores brasileiros que discutem a respeito da ética algorítmica que fundamenta a vida e o cotidiano contemporâneo sob diversas faces, seja a partir de mecanismos de automação em prol de vigilância e controle, seja a partir de aparatos de extremo poder sobre dinâmicas de representação. Este último caso, como se configura a problemática dos bancos de imagens, demonstra como a lógica algorítmica pode mascarar potência decisória sob a percepção da falácia da neutralidade tecnológica. Ao serem propostas e programadas por pessoas, essas tecnologias já nascem imbricadas de vieses discriminatórios que devem ser discutidos e eliminados, uma vez que ajudam a compor o imaginário da realidade de desigualdade social. Assim, este trabalho serve à exposição desses vieses e insere a importância de que processos de tagueamento e algoritmização de imagens obedeçam a regulações importantes com vistas à diminuição dos modos de opressão em gênero e raça.

Parte de projeto de pesquisa ampliado, que visa quantificar estes resultados exploratórios e oferecer um mapeamento dos modos de opressão em gênero, raça e classe em bancos de imagens digitais, este trabalho adentra em grupos de estudo sobre colonialidade algorítmica e práticas tecnológicas de produção de discursos coloniais. Nesse sentido, reconhece a importância da compreensão desses mecanismos como agentes ubíquos na cultura contemporânea, cujo impacto ultrapassa a problemática da representação, mas influencia na produção de subjetividades e na construção discursiva que legitima e autoriza as desigualdades. Portanto, demarcar a opacidade, 
a não neutralidade e os vieses imbricados nessas tecnologias é entendê-las tanto em sua potência formadora como nas suas possibilidades de produção de injustiças e de fortalecimento de privilégios sociais.

\section{Referências}

Aiello, G. e Woodhouse, A. (2016). When corporations come to define the visual politics of gender: The case of Getty Images. Journal of Language and Politics, 15(3), 351-366. DOI: https://doi.org/10.1075/ jlp.15.3.08aie

Bhabha, H. (1992). A questão do "outro": diferença, discriminação e o discurso do colonialismo. Em H. B. de Hollanda (ed.), Pós-modernismo e política (pp. 177-203). Rio de Janeiro: Rocco.

Akotirene, C. (2019). Interseccionalidade. São Paulo: Pólen Produção Editorial LTDA.

Araújo, J. Z. (2006). A força de um desejo-a persistência da branquitude como padrão estético audiovisual. Revista USP, (69), 72-79. DOI: https://doi.org/10.11606/issn.2316-9036.v0i69p72-79

Astobiza, A. M. (2017). Ética algorítmica: implicaciones éticas de una sociedad cada vez más gobernada por algoritmos. Dilemata, (24), 185-217. Recuperado de https://www.dilemata.net/revista/index.php/dilemata/article/view/412000107

Bairros, L. (1995). Nossos feminismos revisitados. Revista Estudos Feministas, 3(2), 458. Recuperado de https://periodicos.ufsc.br/index.php/ref/article/view/16462

Baker, C. N. (2005). Images of women's sexuality in advertisements: A content analysis of black- and white-oriented women's and men's magazines. Sex Roles, 52(1-2). DOI: https://doi.org/10.1007/ s11199-005-1190-y 
Benjamin R. Race after technology: abolitionist tools for the new Jim code. Medford, MA: Polity, 2019.

Bernardino-Costa, J. (2007). Colonialidade do poder e subalternidade: os sindicatos das trabalhadoras domésticas no Brasil. Revista Brasileira do Caribe, 7(14), 311-345. Recuperado de http://www.periodicoseletronicos.ufma.br/index.php/rbrascaribe/article/view/2447

Bernardino-Costa, J. e Grosfoguel, R. (2016). Decolonialidade e perspectiva negra. Sociedade e Estado, 31(1), 15-24. DOI: https://doi. org/10.1590/S0102-69922016000100002

Birhane, A. (2020). Colonização algorítmica da África. Em T. Silva (ed.), Comunidades, algoritmos e ativismos digitais: olhares afrodiaspóricos (pp. 156-165). São Paulo: Editora Literarua.

Birhane, A. e Cummins, F. (2019). Algorithmic injustices: Towards a relational ethics. arXiv preprint arXiv:1912.07376. Recuperado de https://arxiv.org/abs/1912.07376

Bueno, W. (2020). Imagens de controle: um conceito do pensamento de Patricia Hill Collins. Porto Alegre: Zouk Editora.

Buolamwini, J. e Gebru, T. (2018). Gender shades: Intersectional accuracy disparities in commercial gender classification. Em Conference on fairness, accountability and transparency (pp.77-91). Recuperado de http://proceedings.mlr.press/v81/buolamwini18a/buolamwini18a.pdf

Carneiro, S. (2003). Enegrecer o feminismo: a situação da mulher negra na América Latina a partir de uma perspectiva de gênero. Em Ashoka Empreendimentos Sociais \& Takano Cidadania (orgs.), Racismos contemporâneos (pp. 4-58). Rio de Janeiro: Takano Editora. Recuperado de https://www.patriciamagno.com.br/wp-content/uploads/2021/04/CARNEIRO-2013-Enegrecer-o-feminismo.pdf 
Carneiro, S. (1995). Gênero raça e ascensão social. Revista Estudos Feministas, 3(2), 544-544.

Carrera, F. (2020a). Racismo e sexismo em bancos de imagens digitais: análise de resultados de busca e atribuição de relevância na dimensão financeira/profissional. Em T. Silva (ed.), Comunidades, algoritmos e ativismos digitais: olhares afrodiaspóricos (pp. 139-154). São Paulo: Editora Literarua.

Carrera, F. (2020b). A raça e o gênero da estética e dos afetos: algoritmização do racismo e do sexismo em bancos contemporâneos de imagens digitais. MATRIZes, 14(2), 217-240. DOI: https://doi. org/10.11606/issn.1982-8160.v14i2p217-240

Carrera, F. e Carvalho, D. (2020). Algoritmos racistas: a hiper-ritualização da solidão da mulher negra em bancos de imagens digitais. Galáxia, (43), 99-114. DOI: https://doi.org/10.1590/198225532020141614

Cesar Guimarães, M. (2019). Geoblocking e geopricing: uma análise à luz da teoria do interesse público de Mike Feintuck. Revista de Direito, Estado e Telecomunicações, 11(2).DOI: https://doi.org/10.26512/ lstr.v11i2.27025

Cole, T. (2012). The white-savior industrial complex. The Atlantic, 21 (March).

Collins, P. (2002). Blackfeminist thought ( $2^{\mathrm{a}}$ ed.). Nova York: Routledge.

Corossacz, V. R. (2014). Cor, classe, gênero: aprendizado sexual e relações de domínio. Revista Estudos Feministas, 22(2), 521-542. DOI: https://doi.org/10.1590/S0104-026X2014000200007

Crenshaw, K. (2016). Demarginalizing the intersection of race and sex: A black feminist critique of antidiscrimination doctrine, feminist theory and antiracist politics. Em H. Lutz, M. T. Vivar e L. Supik 
(eds.), Framing intersectionality: Debates on a multi-faceted concept in gender studies. Farnham : Routledge.

da Silva, S. R. (2007). "Eu não vivo sem celular”: sociabilidade, consumo, corporalidade e novas práticas nas culturas urbanas. Intexto, 2(17), 1-17. Recuperado de https://seer.ufrgs.br/intexto/article/view/3457/4131

da Silveira, S. A. (2001). Exclusão digital: a miséria na era da informação. São Paulo: Editora Fundação Perseu Abramo.

Emenda constitucional n. ${ }^{\circ}$ 72, de 2 de abril de 2013, da Presidência da República, Casa Civil, Subchefia para Assuntos Jurídicos (2013). Recuperado de http://www.planalto.gov.br/ccivil_03/constituicao/ emendas/emc/emc72.htm

Eubanks, V. (2018). Automating inequality: How high-tech tools profile, police, and punish the poor. Nova York: St. Martin's Press.

Frosh, P. (2001). Inside the image factory: Stock photography and cultural production. Media, Culture \& Society, 23(5), 625-646. DOI: https://doi.org/10.1177/016344301023005005

Gilliam, A. (1995). Negociando a subjetividade de mulata no Brasil. Revista Estudos Feministas, 3(2), 525. Recuperado de https://periodicos.ufsc.br/index.php/ref/article/view/16471

Brown Givens, S. M. e Monahan, J. L. (2005). Priming mammies, jezebels, and other controlling images: An examination of the influence of mediated stereotypes on perceptions of an African American woman. Media Psychology, 7(1), 87-106. DOI: https://doi. org/10.1207/S1532785XMEP0701_5

Goffman, E. (1979). Gender Advertisements. Cambridge, Mass.: Harvard University Press. 
Gonzalez, L. (1988). A categoria político-cultural de amefricanidade. Tempo brasileiro, 92(93), 69-82.

Grohmann, R. (2020). Plataformização do trabalho: entre dataficação, financeirização e racionalidade neoliberal. Revista Eptic, 22(1), 106122. Recuperado de https://seer.ufs.br/index.php/eptic/article/ view/12188

Jewell, K. S. (1993). From mammy to Miss America and beyond: Cultural images and the shaping of U.S. social policy. Nova York: Routledge.

Lei Complementar n. ${ }^{\circ} 150$, de $1^{\circ}$ de junho de 2015, da Presidência da República, Casa Civil, Subchefia para Assuntos Jurídicos (2015). Recuperado de http://www.planalto.gov.br/ccivil_03/leis/lcp/ Lcp150.htm

Lemos, A. (2009). Cultura da mobilidade. Revista Famecos, 16(40), 28-35.

Lemos, A. (2013). Cidades inteligentes. GV EXECUTIVO, 12(2), 46-49. DOI: https://doi.org/10.12660/gvexec.v12n2.2013.20720

Lima, C. A. R. e Calazans, J. D. H. C. (2013). Pegadas digitais: "big data" e informação estratégica sobre o consumidor. NT-Sociabilidade, novas tecnologias, consumo e estratégias de mercado do SIMSOCIAL. Recuperado de http://gitsufba.net/anais/wp-content/ uploads/2013/09/13n2-pegadas_49483.pdf

Lorde, A. (2003). La hermana, la extranjera: artículos y conferencias. Madrid: Horas y horas.

Mbembe, A. N. (2016). Necropolítica. Arte \& Ensaios. n-1 edições (32), 123-151.

McLaughlin, T. L. e Goulet, N. (1999). Gender advertisements in magazines aimed at African Americans: A comparison to their occur- 
rence in magazines aimed at Caucasians. Sex Roles, 40(1-2), 61-71. DOI: https://doi.org/10.1023/A:1018878317017

Mejías, U. e Couldry, N. (2019). Colonialismo de datos: repensando la relación de los datos masivos con el sujeto contemporáneo. Virtualis, 10(18), 78-97. Recuperado de https://www.revistavirtualis. $\mathrm{mx} /$ index.php/virtualis/article/view/289/290

Mohamed, S., Png, M. T. e Isaac, W. (2020). Decolonial AI: Decolonial Theory as Sociotechnical Foresight in Artificial Intelligence. Philosophy \& Technology, 1-26. DOI: https://doi.org/10.1007/s13347020-00405-8

Nascimento, A. do (1982). O negro revoltado. Rio de Janeiro: Editora Nova Fronteira.

Noble, S. U. (2018). Algorithms of oppression: How search engines reinforce racism. nyu Press. DOI: https://doi.org/10.2307/j.cttlpwt9w5

Osoba, O. A. e Welser IV, W. (2017). An intelligence in our image: The risks of bias and errors in artificial intelligence. Santa Monica: Rand Corporation.

Pacheco, A. C. L. (2008). "Branca para casar, mulata paraf... e negra para trabalhar": escolhas afetivas e significados de solidão entre mulheres negras em Salvador, Bahia (tese de doutorado em Ciências Sociais). IFCH, Campinas.

Pinheiro, L., Lira, F., Rezende, M. e Fontoura, N. (2019). Os desafios do passado no trabalho doméstico do século XXI: reflexões para o caso brasileiro a partir dos dados da PNAD contínua. Recuperado de http:// repositorio.ipea.gov.br/handle/11058/9538

Plous, S. e Neptune, D. (1997). Racial and gender biases in magazine advertising: A contente-analytic study. Psychology of Women Quartely, 
21(4),627-644.DOI: https://doi.org/10.1111/j.1471-6402.1997. tb00135.x

Quijano, A. (2002). Colonialidade, poder, globalização e democracia. Novos rumos, 37(17), 4-28. DOI: https://doi.org/10.36311/01025864.17.v0n37.2192

Reynolds-Dobbs, W., Thomas, K. M. e Harrison, M. S. (2008). From mammy to superwoman: Images that hinder Black women's career development. Journal of Career Development, 35(2), 129-150. DOI: https://doi.org/10.1177/0894845308325645

Sagesse, G. S. R., Marini, M., Lorenzo, R. A., Simões J. A. e Cancela, C. D. (orgs.) (2018). Marcadores sociais da diferença: gênero, sexualidade, raça e classe em perspectiva antropológica. São Paulo: Editora Gramma.

Schucman, L. V. (2014). Sim, nós somos racistas: estudo psicossocial da branquitude paulistana. Psicologia \& Sociedade, 26(1), 11. DOI: https://doi.org/10.1590/S0102-71822014000100010

Silva, T. (2019). Teoria racial crítica e comunicação digital: conexões contra a dupla opacidade. Em Anais do $42^{\circ}$ Congresso Brasileiro de Ciências da Comunicação. Sociedade Brasileira de Estudos Interdisciplinares da Comunicação. Belém, Pará. Recuperado de https://portalintercom. org.br/anais/nacional2019/resumos/R14-0434-1.pdf

Silva, T. (2020). Racismo algorítmico em plataformas digitais: microagressões e discriminação em código. Em T. Silva (ed.), Comunidades, algoritmos e ativismos digitais: olhares afrodiaspóricos (pp. 121-135). São Paulo: Editora Literarua.

Souza, C. (2008). A solidão da mulher negra - sua subjetividade e seu preterimento pelo homem negro na cidade de São Paulo. (dissertação em Ciências Sociais). Pontifícia Universidade Católica de São Paulo, 
São Paulo, Brasil. Recuperado de https://tede2.pucsp.br/handle/handle/3915

Sovik, L. R. (2009). Aqui ninguém é branco. Rio de Janeiro: Aeroplano.

Tori, R. (2018). Educação sem distância: as tecnologias interativas na redução de distâncias em ensino e aprendizagem (v. 9). São Paulo: Artesanato Educacional LTDA. Recuperado de https://edisciplinas. usp.br/pluginfile.php/5147288/mod_resource/content/1/Educa\%C3\%A7\%C3\%A3o\%20Sem\%20Dist\%C3\%A2ncia.pdf

Weiss, M. C., Bernardes, R. C. e Consoni, F. L. (2017). Cidades inteligentes: casos e perspectivas para as cidades brasileiras. Revista Tecnológica da Fatec Americana, 5(1), 1-13. Recuperado de https://fatecbr.websiteseguro.com/revista/index. $\mathrm{php} / \mathrm{RTecFatecAM} /$ article/view/137

West, C. M. (1995). Mammy, Sapphire and Jezebel: Historical images of Black women and their implications for psychotherapy. Psychotherapy, 32(3), 458-466. DOI: https://doi.org/10.1037/00333204.32.3.458

Woodard, J. B. e Mastin, T. (2005). Black womanhood: Essence and its treatment of stereotypical images of Black women. Journal of Black Studies, 36(2), 264-281. DOI: https://doi. org/10.1177/0021934704273152

Vieira, N. S. e de Almeida, T. M. C. (2019). O trabalho doméstico e as babás: lutas históricas e ameaças atuais. Sociedade e Cultura, 22(1). DOI: https://doi.org/10.5216/sec.v22i1.57899 